\title{
Medicine at nanoscale: a new horizon
}

\author{
This article was published in the following Dove Press journal: \\ International Journal of Nanomedicine \\ 16 June 2012 \\ Number of times this article has been viewed
}

\section{Asad U Khan \\ Medical Microbiology and Molecular Biology Laboratory, Interdisciplinary Biotechnology Unit, Aligarh Muslim University, Aligarh, India}

\section{Dear Editor}

Concerning the recent article published in your journal on antibiofilm surface functionalization of catheters. ${ }^{1}$ This is an admirable approach to inhibit biofilm formation on the surfaces of various implants. Currently, a number of biomedical devices and implants are commonly used in hospitals and clinics. Over the past few decades, a number of knee and hip implants have been introduced to save lives and restore quality of life. Moreover, a significant increase in the use of stents, heart valves, vascular grafts, catheters, and other implantable devices are being introduced worldwide. However, regrettably, these surfaces are prone to microbial infections and hence device-related infections have become a major source of infection which may ultimately lead to a high mortality rate in the hospital setting. ${ }^{2}$

Another major problem is the worldwide spread of multidrug resistance, especially of the newly discovered NDM-1 superbug. The latest metallo beta-lactamase, named NDM-1 (New Delhi metallo beta-lactamase) has been identified as a novel class of carbapenemases in enterobacteriaceae. ${ }^{3}$ Due to its spread, only a limited number of antibiotics can control infections with this agent. In this situation, there is an urgent need for research on biomaterials and design of surfaces that are resistant to infection and biofilms so that microbial infection and biofilm formation can be controlled. ${ }^{4}$ A number of promising approaches have been developed to control these infections on the surfaces of various devices. However, nanotechnology-based approaches are anticipated to provide new breakthroughs for prevention of biofilm-mediated infections via the broadened use of atomic-scaled nanomaterials.

Lellouche et al $^{1}$ coated catheters with MgF2 nanoparticles using a sonochemical synthesis protocol. This preparation and coating procedure resulted in a uniform $\mathrm{MgF} 2$ nanoparticle layer on both sides of the catheter. These nanoparticle-coated catheters were investigated for their ability to control the formation of bacterial biofilm. Moreover, the potential cytotoxicity of MgF2 nanoparticles was investigated in human and mammalian cell lines. No significant reduction in mitochondrial metabolism was found. These results indicate that surface modification of catheters with MgF2 nanoparticles can be effective in preventing bacterial colonization and can make catheters available with enduring self-sterilizing properties.

Recently, we explored gold nanoparticles $(21 \pm 2.5 \mathrm{~nm}$ and $0.2 \mathrm{mg} / \mathrm{mL})$ and methylene blue $(20 \mu \mathrm{g} / \mathrm{mL})$ conjugation as a potential treatment for Candida biofilm. Type 1 phototoxicity against biofilm was demonstrated and confirmed by 
fluorescence spectroscopy. Therefore, gold nanoparticle conjugate-mediated photodynamic therapy may also be used against common nosocomially acquired refractory Candida albicans biofilm. ${ }^{5}$

In one of the relevant studies, Chifiriuc et $\mathrm{al}^{6}$ explored functionalized magnetite nanoparticles with oleic acid as a surfactant. Core-shell nanoparticles $\left(\mathrm{Fe}_{3} \mathrm{O}_{4} /\right.$ oleic acid: $\left.\mathrm{CHCl}_{3}\right)$ were used to coat pieces of catheter by applying a magnetic field on nanofluid, while the $\mathrm{CHCl}_{3}$ diluted essential oil was pertained by adsorption in a secondary covering treatment. Fungal adherence and development of biofilm were strongly inhibited in the presence of these new core-shell/coated shellbased essential oil of Rosmarinus officinalis. Hence, it can be used to inhibit fungal adherence and could be of a great interest in the biomedical field, opening up new vistas for the design of film-coated surfaces with antibiofilm properties. ${ }^{6}$

Silver nanoparticles are recognized as promising candidates due to their significant antimicrobial activity; however, there are two major problems with these nanoparticles, ie, they are highly toxic to healthy cells and cannot eradicate bacterial biofilms. Therefore, new technologies are being developed to overcome these limitations, consisting of multimodal nanoparticles having a magnetic core and a silver ring with a ligand gap, which have been used to eradicate bacterial biofilms successfully with no detrimental effect on healthy cells. ${ }^{7}$ This will require special consideration in future work, in which alternative nonmaterial compounds that can inhibit bacterial and fungal colonization of catheter surfaces should be developed.

\section{Disclosure}

The author reports no conflicts of interest in this letter.

\section{References}

1. Lellouche J, Friedman A, Lahmi R, et al. Antibiofilm surface functionalization of catheters by magnesium fluoride nanoparticles. Int $J$ Nanomedicine. 2012;7:1175-1188.

2. Mack D, Rohde H, Harris LG, et al. Biofilm formation in medical devicerelated infection. Int J Artif Organs. 2006;29(4):343-359.

3. Yong D, Toleman MA, Giske CG, et al. Characterization of a new metallo-beta-lactamase gene, bla(NDM-1), and a novel erythromycin esterase gene carried on a unique genetic structure in Klebsiella pneumoniae sequence type 14 from India. Antimicrob Agents Chemother. 2009;53(12):5046-5054.

4. Khan AU, Nordmann P. Spread of carbapenemase NDM-1 producers: The situation in India and what may be proposed. Scand J Infect Dis. April 12, 2012. [Epub ahead of print].

5. Khan S, Alam F, Azam A, et al. Gold nanoparticles enhance methylene blue induced photodynamic therapy: A novel therapeutic approach to inhibit Candida albicans biofilm. Int J Nanomedicine. 2012.

6. Chifiriuc MC, Grumezescu V, Grumezescu AM, et al. Hybrid magnetite nanoparticles/Rosmarinus officinalis essential oil nanobiosystem with antibiofilm activity. Nanoscale Res Lett. 2012;7(1):209.

7. Mahmoudi M, Serpooshan V. Silver-coated engineered magnetic nanoparticles are promising for the success in the fight against antibacterial resistance threat. ACS Nano. 2012;6(3):2656-2664.
International Journal of Nanomedicine

\section{Publish your work in this journal}

The International Journal of Nanomedicine is an international, peerreviewed journal focusing on the application of nanotechnology in diagnostics, therapeutics, and drug delivery systems throughout the biomedical field. This journal is indexed on PubMed Central, MedLine, CAS, SciSearch ${ }^{\circledR}$, Current Contents ${ }^{\circledR} /$ Clinical Medicine,

\section{Dovepress}

Journal Citation Reports/Science Edition, EMBase, Scopus and the Elsevier Bibliographic databases. The manuscript management system is completely online and includes a very quick and fair peer-review system, which is all easy to use. Visit http://www.dovepress.com/ testimonials.php to read real quotes from published authors. 